\title{
Comparison of Chemical and Enzymatic Methods for the Transesterification of Waste Fish Oil Fatty Ethyl Esters with Different Alcohols
}

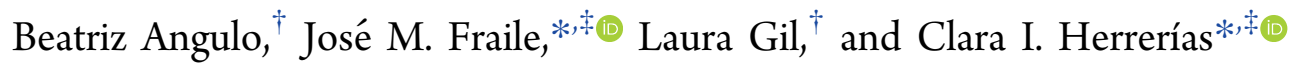 \\ ${ }^{\dagger}$ Solutex GC S.L., P. I. El Zafranar, E-50550 Mallén, Zaragoza, Spain \\ ${ }^{\ddagger}$ Instituto de Síntesis Química y Catálisis Homogénea (ISQCH), Facultad de Ciencias, CSIC-Universidad de Zaragoza, C/ Pedro \\ Cerbuna 12, E-50009 Zaragoza, Spain
}

\section{Supporting Information}

ABSTRACT: Fatty acid esters of 2-ethyl-1-hexanol (EH), 2-hexyl-1-decanol (HD), and isopropanol have been obtained from a mixture of ethyl esters obtained as a fish oil byproduct. Homogeneous base catalysis with alkaline hydroxides and alkoxides has been compared with the use of two commercially available immobilized lipases. The enzymatic methodology is more efficient in the case of the largest alcohol (HD) mainly because of the high stability of the immobilized enzymes upon recovery and reuse. In contrast, the use of a base as a catalyst is highly favorable in the case of

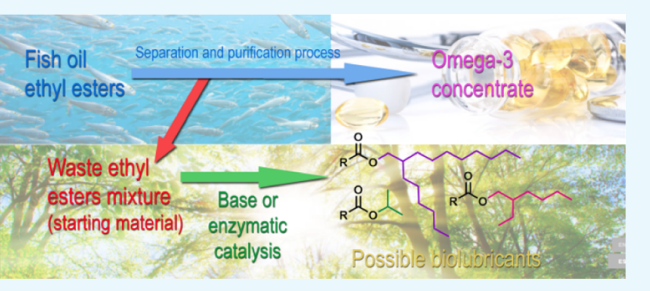
isopropanol because of the rather poor activity of the lipases and the low price of the bases. With EH, the activity of lipases is good but the recoverability is not as efficient; hence, basic catalysts are again the most attractive alternative. The mixtures of esters obtained may be useful as hydraulic liquids given their viscosity values.

\section{INTRODUCTION}

Fatty esters of simple alcohols are used in a wide variety of applications. Lower esters, for example, are mainly used as biodiesel fuel, ${ }^{1}$ which mostly comprises methyl and ethyl fatty esters, along with some isopropyl esters, ${ }^{2,3}$ prepared by the base-catalyzed transesterification of triglycerides, although the use of lipases is a topic of current interest. ${ }^{4,5}$ These lower esters, as well as some higher esters, are also components in a large number of different consumer goods, such as lubricants, ${ }^{6}$ coolants for metal machining, ${ }^{7}$ drilling fluids, ${ }^{8}$ or printing inks, ${ }^{9,10}$ and are also used as biodiesel additives ${ }^{11,12}$ or reagent solvents in alkyd resins. ${ }^{13}$

2-Ethylhexyl esters are among the most common simple fatty esters of higher alcohols used in most of the applications mentioned above. Apart from acid-catalyzed ${ }^{14}$ or lipasecatalyzed $^{15}$ esterification of free fatty acids (FAs), these compounds have been prepared by transesterification using two alternative methods. Thus, base-catalyzed transesterification has been applied to FA methyl esters (FAMEs) using $\mathrm{MeONa},{ }^{8}$ with an alcohol/FAME molar ratio of 2 , high vacuum conditions ( $1.5 \mathrm{mbar})$, and relatively large amounts of the base $(2 \% \mathrm{w} / \mathrm{w}$ with respect to the total mass of reactants, which represents around $20 \mathrm{~mol} \%$ with respect to FAMEs), at $70-100{ }^{\circ} \mathrm{C}$. On the other hand, lipases have been used as biocatalysts for the transesterification of FAMEs ${ }^{16,17}$ or triglycerides. $^{18,19}$ In the large-scale (28 $\mathrm{kg}$ of FAMEs) optimized process, ${ }^{16}$ milder conditions were used (alcohol/ FAME molar ratio of $1.47,55^{\circ} \mathrm{C}, 100-150 \mathrm{~mm} \mathrm{Hg}$ ), although a large quantity of the enzyme $(9.3 \% \mathrm{w} / \mathrm{w}$ with respect to the total weight of reactants), which in principle should be recoverable and reusable, is required.

Other 2-alkyl-1-alkanols have also been used to prepare this kind of esters, for example, 2-hexyl-1-decyl esters, which have been described as potentially useful cosmetic ingredients. ${ }^{20,21}$ To the best of our knowledge, the synthesis of these esters by transesterification has not been described in the literature.

In these examples, branching occurs at the 2-position of a primary alcohol. However, it is also possible to introduce branching in the 1-position by using a secondary alcohol, such as isopropanol. Thus, isopropyl fatty esters have been prepared from triglycerides via basic catalysis, by the formation of sodium isopropoxide using metallic $\mathrm{Na},{ }^{2,11} \mathrm{MeONa},{ }^{13}$ or alkali metal hydroxides $(\mathrm{NaOH}$ and $\mathrm{KOH})$ as the base. ${ }^{22}$ The use of lipases for the transesterification of triglycerides with isopropanol has also been explored. ${ }^{23}$

The importance of omega-3 polyunsaturated FAs (PUFAs) in human health, ${ }^{24,25}$ and their low consumption in many developed countries, has fostered the development of many nutritional products enriched with omega- 3 concentrates, the main feedstock of which is still fish. ${ }^{26}$ The manufacture of omega-3 concentrates implies their separation from other FAs present in fish oil, which are then considered to be waste. In the context of the circular economy, ${ }^{27}$ there are several levels to close the circle (reuse, remanufacturing, recycling, and disposal); therefore, waste must be considered as simply

Received: September 24, 2019

Accepted: December 19, 2019

Published: January 17, 2020 
Table 1. Transesterification of Fish Oil FAEEs with EH and Bases at $90{ }^{\circ} \mathrm{C}$

\begin{tabular}{|c|c|c|c|c|c|c|c|}
\hline \multirow[b]{2}{*}{ entry } & \multirow[b]{2}{*}{ base } & \multirow[b]{2}{*}{ EH/FAEE/base (molar ratio) } & \multirow[b]{2}{*}{$P$ (mbar) } & \multicolumn{4}{|c|}{$\%$ conv } \\
\hline & & & & $1 \mathrm{~h}$ & $3 \mathrm{~h}$ & $4 \mathrm{~h}$ & $6 \mathrm{~h}$ \\
\hline 1 & $\mathrm{KOH}$ & $500: 100: 5$ & 100 & 77 & & & 77 \\
\hline 2 & $\mathrm{KOH}$ & $500: 100: 5$ & 50 & 86 & & 89 & \\
\hline 3 & $\mathrm{KOH}$ & $500: 100: 5$ & 10 & 95 & & 100 & \\
\hline 4 & $\mathrm{EtONa}$ & $500: 100: 5$ & 10 & 97 & & 100 & \\
\hline 5 & TBD & $500: 100: 5$ & 10 & 39 & 86 & & 99 \\
\hline 6 & $\mathrm{KOH}$ & $150: 100: 5$ & 10 & 100 & & & \\
\hline 7 & EtONa & $150: 100: 5$ & 10 & 100 & & & \\
\hline 8 & TBD & $150: 100: 5$ & 10 & 70 & 94 & & 99 \\
\hline 9 & $\mathrm{KOH}$ & 150:100:1 & 10 & 89 & & 99 & \\
\hline 10 & EtONa & 150:100:1 & 10 & 100 & & & \\
\hline 11 & TBD & 150:100:1 & 10 & 39 & 47 & & 69 \\
\hline 12 & $\mathrm{KOH}$ & 100:100:1 & 10 & 93 & & 94 & \\
\hline 13 & EtONa & 100:100:1 & 10 & 92 & & 93 & \\
\hline 14 & EtONa & $100: 100: 5$ & 10 & 96 & & 96 & \\
\hline 15 & TBD & $100: 100: 5$ & 10 & 71 & 86 & & 92 \\
\hline
\end{tabular}

another starting material. The energetic valorization/recycling of this waste is one of the less interesting alternatives.

In the edible fish industry, the possible use of waste as biodiesel, which can be considered to be a type of energetic valorization, is an economically interesting alternative. ${ }^{28,29}$ Indeed, the production of biodiesel from fish canning industry waste, using base catalysis, ${ }^{30}$ and from waste sardine oil in a lipase-catalyzed process ${ }^{31}$ has been described. However, the fish oil waste left over after omega-3 separation is still high quality in terms of its characteristics and absence of contaminants. Thus, its transformation into specific bio-based products would represent a new and more attractive valorization alternative (remanufacturing) that has already been proposed to biodiesel manufacturers to extend the potential sales market. ${ }^{16}$

The transformation of biodiesel (FAMEs) into more valuable products has been recently explored for nonedible Tilapia (Oreochromisniloticus) oil by epoxidation and subsequent epoxide ring opening to obtain biolubricants ${ }^{32}$ or by epoxidation of biodiesel from vegetable oils to obtain bioplasticizers. ${ }^{33}$ In this regard, we recently described the transesterification of waste fish oil from omega-3 extraction with trimethylolpropane to obtain mixtures of mono-, di-, and triesters, with the latter showing good properties for use as biolubricants. $^{34}$

In this paper, we compare chemical and enzymatic methods for transesterifying the FA ethyl ester waste left over from fish oil after PUFA extraction using three different alcohols, namely, 2-ethyl-1-hexanol (EH), 2-hexyl-1-decanol (HD), and isopropanol $(\mathrm{iPrOH})$. Similar comparisons are rare in the literature, ${ }^{35}$ where only one type of method is usually studied and optimized. Additionally, some of the key properties of the resulting ester mixtures for use as biolubricants have also been determined.

\section{RESULTS AND DISCUSSION}

A waste mixture of fatty acid ethyl esters (FAEEs) (500-600 ton/year) is generated by Solutex after the extraction of PUFAs from fish oil. This waste mixture contains around $50 \mathrm{wt}$ $\%$ saturated FAs (SFAs), 25 wt \% monounsaturated FAs (MUFAs), and 25 wt \% PUFAs. The average molecular weight of the sample used to calculate the molar ratios was taken to be 296.5 (as methyl oleate). ${ }^{34}$
Base-Catalyzed Reactions. Transesterification Reactions with EH. Preliminary tests showed the need to carry out the reaction under vacuum to ensure high conversion of FAEEs. As the transesterification is an equilibrium reaction, it can be shifted by eliminating one of the products (ethanol) from the reaction mixture. A similar method has previously been applied for the transesterification of FAMEs to eliminate methanol from the reaction mixture. ${ }^{8,16}$ The effect of different reaction parameters (amounts of the base and $\mathrm{EH}$ and pressure) was tested with three different bases, namely, two bases typically used in transesterification reactions $(\mathrm{KOH}$ and EtONa) and one organic strong base (TBD: 1,5,7triazabyciclo[4.4.0]dec-5-ene), as catalysts. The results can be found in Table 1 .

The starting conditions were $5 \mathrm{~mol} \% \mathrm{KOH}, \mathrm{EH} / \mathrm{FAEE}$ molar ratio of 5 , and 100 mbar (entry 1 ), which resulted in $77 \%$ conversion in $1 \mathrm{~h}$. Unfortunately, this could not be increased by increasing the reaction time or by adding more $\mathrm{EH}$, thus indicating that equilibrium was reached. However, this equilibrium can be shifted with a more efficient elimination of ethanol upon decreasing the pressure to 50 mbar (entry 2) or to $10 \mathrm{mbar}$ (entry 3 ), which led to total conversion in $4 \mathrm{~h}(95 \%$ in $1 \mathrm{~h})$. This pressure was therefore used throughout this study. The result was essentially identical when using EtONa (entry 4), whereas the reaction with TBD was much slower (entry 5).

Rather surprisingly, the results were slightly (entries 6 and 7) or significantly (entry 8 ) better when the amount of alcohol was reduced to $1.5 \mathrm{EH} / \mathrm{FAEE}$ molar ratio, with quantitative conversion in $1 \mathrm{~h}$ when using $\mathrm{KOH}$ or EtONa, and more than $90 \%$ conversion in $3 \mathrm{~h}$ with TBD. The dilution of FAEEs with larger amounts of alcohol may explain this effect. As expected, a decrease in the reaction rate, which was much more marked in the case of TBD (entry 11) than with $\mathrm{KOH}$ (entry 9), was observed when the amount of the base was reduced to $1 \mathrm{~mol}$ $\%$, whereas EtONa still afforded quantitative conversion in $1 \mathrm{~h}$ (entry 10). Use of a stoichiometric amount of alcohol led to conversion values in the $92-96 \%$ range, irrespective of the amount of the base (entries 12-15), although this might be due to the averaged molecular weight used to calculate the molar amount of FAEEs and the slight variability in the composition of the different batches. 
The conditions of entry 10 were used to scale-up the reaction to $100 \mathrm{~g}$ of fish oil FAEEs, which also gave $100 \%$ conversion in $1 \mathrm{~h}$. These conditions are milder than those reported previously ${ }^{8}$ in all aspects, especially the $\mathrm{EH} /$ ester ratio ( 1.5 instead of 2$)$, amount of the base $(<0.14 \% \mathrm{w} / \mathrm{w}$ instead of $2 \% \mathrm{w} / \mathrm{w})$, and pressure (10 mbar instead of 1.5 mbar), thus leading to a more sustainable method.

Transesterification Reactions with HD. The optimal conditions for transesterification with $\mathrm{EH}$, namely, an $\mathrm{HD} /$ FAEE molar ratio of $1.5,90{ }^{\circ} \mathrm{C}, 10 \mathrm{mbar}$, and $1 \mathrm{~mol} \%$ of the base, were applied to the reaction with HD. These conditions led to little or no conversion at all after $2 \mathrm{~h}$ (Table 2, entries 1 and 2). Increasing the amount of the base to $5 \mathrm{~mol} \%$ was only successful in the case of $\mathrm{KOH}$ (entry 3).

Table 2. Transesterification of Fish Oil FAEEs with HD and Bases at $10 \mathrm{mbar}$

\begin{tabular}{cccccccc} 
& & & & & \multicolumn{2}{c}{$\%$ conv. } \\
\cline { 5 - 8 } entry & base & $\begin{array}{c}\text { HD/FAEEs/base } \\
(\text { molar ratio })\end{array}$ & $\begin{array}{c}\text { temp. } \\
\left({ }^{\circ} \mathrm{C}\right)\end{array}$ & solvent & $1 \mathrm{~h}$ & $2 \mathrm{~h}$ \\
1 & $\mathrm{KOH}$ & $150: 100: 1$ & 90 & no & & 9 \\
2 & EtONa & $150: 100: 1$ & 90 & no & & 0 \\
3 & $\mathrm{KOH}$ & $150: 100: 5$ & 90 & no & 98 & \\
4 & EtONa & $150: 100: 5$ & 90 & no & & 11 \\
5 & EtONa & $150: 100: 5$ & 120 & no & 94 & 99 \\
6 & EtONa & $150: 100: 5$ & 90 & tBuOH & 93 & 99
\end{tabular}

One possible reason for this behavior is the higher viscosity of $\mathrm{HD}$ in comparison with $\mathrm{EH}$, which may hinder the correct mixing of the reagents and the basic catalyst. Indeed, the immiscibility of the reactants has also been noted by other authors in both esterification ${ }^{36}$ and transesterification ${ }^{37}$ reactions. Different types of solutions to this problem, such as ultrasound irradiation ${ }^{37}$ or use of a fluidized bed reactor with heterogeneous catalysts at high temperature, ${ }^{38}$ have been suggested. In our case, two strategies were addressed. Thus, first, the temperature was increased to $120{ }^{\circ} \mathrm{C}$ (entry 5) in order to reduce the viscosity and improve the miscibility of all the reaction components. In addition, second, tert-butanol was added as a nonreactive solvent (entry 6) for the same purpose. Both strategies were successful to the same extent, leading to nearly quantitative conversions after $2 \mathrm{~h}$.

Transesterification Reactions with Isopropanol. In the case of isopropanol, two difficulties, namely, the lower reactivity of the secondary alcohol and the similar boiling points of isopropanol and ethanol, which preclude the use of vacuum to displace the equilibrium and limit the reaction temperature, must be overcome. As such, all tests were carried out under reflux and the amounts of the base and isopropanol were optimized (Table 3 ).

The favorable conditions for the other two alcohols $(5 \mathrm{~mol}$ $\% \mathrm{KOH}$ and 5 equiv alcohol) were unsuccessful in this case (entry 1), although the conversion could be increased from 19 to $46 \%$ by increasing the amount of isopropanol up to a limit of $50 \mathrm{iPrOH} / \mathrm{FAEE}$ molar ratio (entries 2-4). The main problem seems to be the consumption of the base, given that the equilibrium could not be shifted by evaporating the mixture of solvents and addition of new isopropanol. Moreover, the conversion could be increased up to $90 \%$ by using higher amounts of the base (entries 5 and 6). Finally, significantly improved results were obtained with EtONa [64\%
Table 3. Transesterification of Fish Oil FAEEs with Isopropanol ( $i \mathrm{PrOH})$ and Bases under Reflux

\begin{tabular}{|c|c|c|c|}
\hline entry & base & iPrOH/FAEEs/base (molar ratio) & $\% \operatorname{conv}^{a}$ \\
\hline 1 & $\mathrm{KOH}$ & $500: 100: 5$ & 19 \\
\hline 2 & $\mathrm{KOH}$ & $1000: 100: 5$ & 24 \\
\hline 3 & $\mathrm{KOH}$ & $5000: 100: 5$ & 46 \\
\hline 4 & $\mathrm{KOH}$ & $10000: 100: 5$ & 44 \\
\hline 5 & $\mathrm{KOH}$ & 5000:100:10 & 88 \\
\hline 6 & $\mathrm{KOH}$ & $5000: 100: 15$ & 90 \\
\hline 7 & EtONa & $5000: 100: 5$ & 64 \\
\hline 8 & EtONa & 5000:100:10 & 97 \\
\hline 9 & EtONa & 5000:100:15 & 97 \\
\hline
\end{tabular}

${ }^{a}$ Equilibrium conversion reached after $1 \mathrm{~h}$.

conversion with $5 \mathrm{~mol} \%$ (entry 7 ) and $97 \%$ conversion with $10 \mathrm{~mol} \mathrm{\%}$ (entry 8)].

Consequently, $10 \mathrm{~mol} \%$ of this latter base was chosen for scaling-up of the process for $100 \mathrm{~g}$ of fish oil FAEEs (Table 4).

Table 4. Scaling-up of the Transesterification of Fish Oil FAEEs (100 g) with Isopropanol (iPrOH) and EtONa under Reflux

$\begin{array}{ccc}\text { entry } & i \text { PrOH/FAEEs/EtONa (molar ratio) } & \%_{\text {conv }^{a}} \\ 1 & 1000: 100: 10 & 86 \\ 2 & 2000: 100: 10 & 92 \\ 3 & 3000: 100: 10 & 95 \\ 4 & 1000: 100: 5 & 86 \\ & 1000: 100: 10^{b} & 96 \\ & 1000: 100: 15^{b} & 99\end{array}$

${ }^{a}$ Equilibrium conversion reached after $1 \mathrm{~h} .{ }^{b}$ Evaporation of the solvents and addition of a solution of EtONa in $i \mathrm{PrOH}$ to obtain this molar ratio.

Under these conditions, a lower volume of isopropanol was used in order to reduce the reactor volume required. In the range of $10-30 \mathrm{PrOH} / \mathrm{FAEE}$ molar ratio, the conversions reached $86-95 \%$ (entries 1-3). Quantitative conversion was only achieved by using a combination of evaporation of the mixture of solvents, with addition of new EtONa solution in isopropanol (entry 4, three steps).

The preparation of isopropyl fatty esters has been described in the literature following a similar procedure but using triglycerides. ${ }^{13}$ The authors of this study used a lower amount of isopropanol (only $55 \mathrm{~g}$ per $100 \mathrm{~g}$ of oil versus $608 \mathrm{~g}$ in our case) but a higher amount of the base ( $4.8 \mathrm{~g}$ per $100 \mathrm{~g}$ of oil versus $2.3 \mathrm{~g}$ ) and a yield of $72 \%$ was obtained compared with $89 \%$ here.

Enzymatic Transesterifications. Two commercially available biocatalysts consisting in immobilized Candida antarctica B lipase (CALB) on two different supports, namely, Novozym $435^{a}$ (CALB immobilized on an acrylic resin, an activity of $10000 \mathrm{U} / \mathrm{g}$ ) and CalB immo Plus C-Lecta ${ }^{b}$ (CALB immobilized on styrene-methacrylate, an activity of $9000 \mathrm{U} / \mathrm{g}$ ), were used.

Transesterification Reactions with EH. In the transesterification reactions catalyzed by immobilized enzymes, the thermal stability of the catalysts required the reaction temperature to be limited to $60{ }^{\circ} \mathrm{C}$. The effect of the temperature and pressure was checked using an EH/FAEE molar ratio of 5 , with $5 \mathrm{wt} \%$ of Novozym 435 (with respect to FAEEs). The stirring speed was also limited to $200 \mathrm{rpm}$ to 
prevent mechanical damage of the catalyst. Figure 1 shows the slower reaction rate at $30{ }^{\circ} \mathrm{C}$ and the need for low pressure to shift the equilibrium to obtain almost quantitative conversion after $6 \mathrm{~h}$.

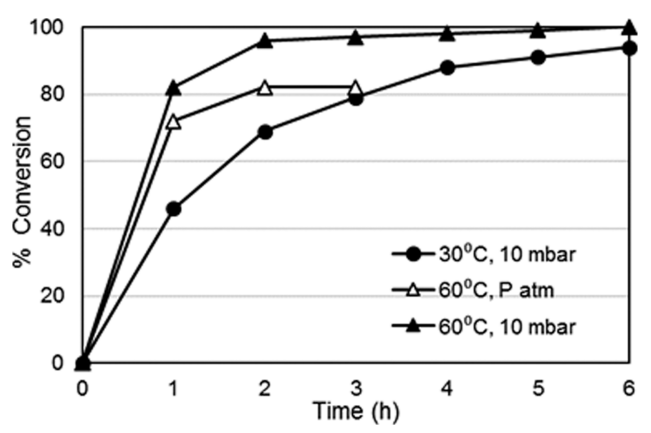

Figure 1. Effect of pressure and temperature on the transesterification of fish oil FAEEs with EH (5 equiv) using Novozym 435 (5 wt \%).

From an economical point of view, it would be advisable to reduce the amount of alcohol to a minimum. Thus, with Novozym 435 (Figure 2), the results were similar or even

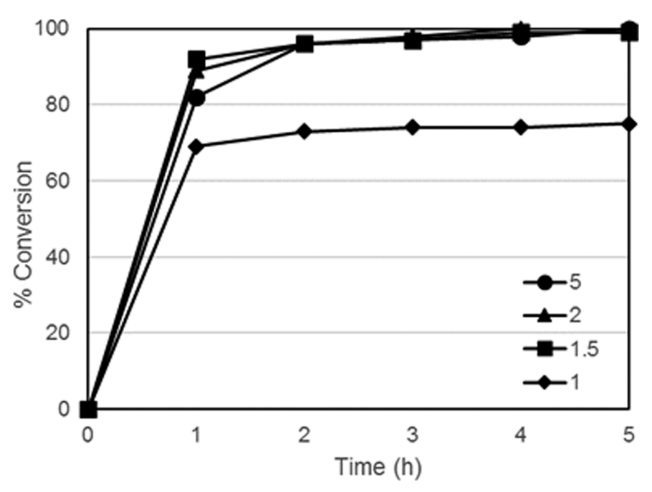

Figure 2. Effect of the EH/FAEE molar ratio on transesterification with Novozym 435 (5 wt \%). Conditions: $60{ }^{\circ} \mathrm{C}, 10 \mathrm{mbar}$, and 200 rpm.

slightly better when the EH/FAEE molar ratio was reduced from 5 to 2 or 1.5. However, use of a stoichiometric amount of $\mathrm{EH}$ led to a maximum of $74 \%$ conversion. As such, 1.5 was considered to be the optimal alcohol/FAEE molar ratio.

These conditions were also tested with CalB immo Plus, with the same results (Figure 3), and the amount of catalysts was reduced to 1 wt \% with both enzymes. The reaction was significantly slower in this case, although a high conversion (>90\%) was obtained after $5 \mathrm{~h}$. However, 5 wt \% was considered to be the optimal amount of the enzyme.

Finally, both enzymes were recovered and reused under the same conditions (Figure 4). Novozym 435 leads to nearly the same results after the first recovery, but the catalytic activity declines from the third to the fifth runs. CalB immo Plus does not behave and Novozym 435 after the first recovery, but its activity declines more slowly, with acceptable results being achieved even after the sixth run.

When compared with analogous processes described in the literature, ${ }^{16}$ the use of higher vacuum (10 mbar instead of 100-150 mbar) allows a significant reduction in the amount of immobilized lipase ( $5 \% \mathrm{w} / \mathrm{w}$ instead of $15 \%)$ while maintaining a fast reaction. Milder temperature conditions

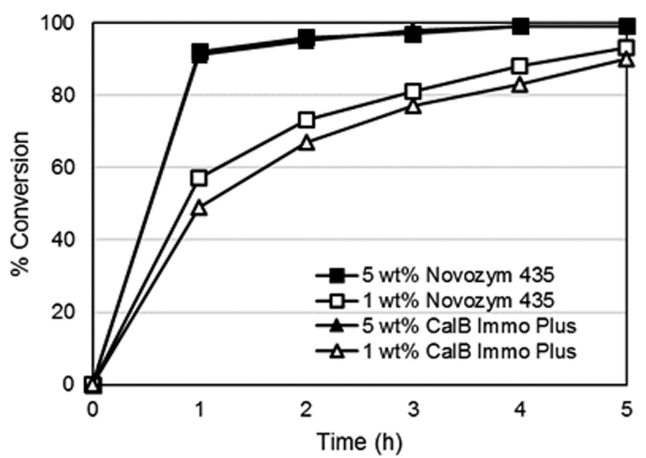

Figure 3. Effect of the enzyme amount on the transesterification of FAEEs with EH (1.5 equiv). Conditions: $60{ }^{\circ} \mathrm{C}, 10 \mathrm{mbar}$, and 200 rpm.
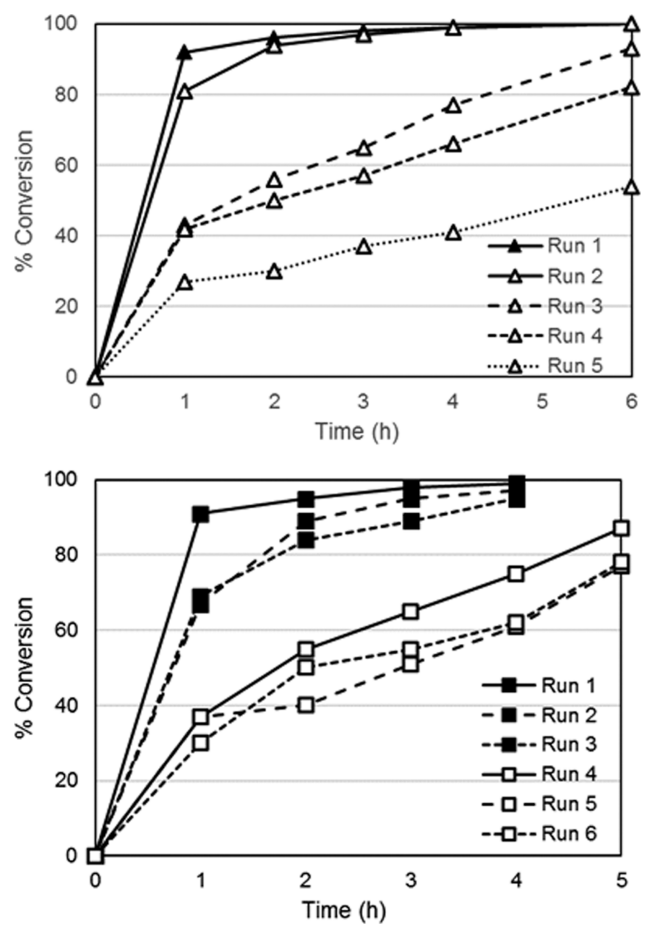

Figure 4. Reuse of Novozym 435 (top) and CalB immo Plus (bottom) in the transesterification of FAEEs with EH (1.5 equiv). Conditions: 5 wt $\%$ enzyme, $60{ }^{\circ} \mathrm{C}, 10 \mathrm{mbar}$, and $200 \mathrm{rpm}$.

$\left(35^{\circ} \mathrm{C}\right)$, amount of the enzyme $(2 \% \mathrm{w} / \mathrm{w})$, and no excess of $\mathrm{EH}$, together with the use of atmospheric pressure, lead to a much slower reaction ( $50 \mathrm{~h}$ for $97 \%$ conversion), ${ }^{17}$ even when compared with our result using only $1 \% \mathrm{w} / \mathrm{w}$ enzyme.

Transesterification Reactions with HD. Given the miscibility problems detected in the base-catalyzed transesterification, the enzymatic reactions were tested at different stirring speeds and with addition of tert-butanol as a solvent to improve the miscibility of the reagents, a strategy already used in the case of lipase-catalyzed transesterification reactions. ${ }^{39}$ As can be seen in Table 5 , the conversions after $6 \mathrm{~h}$ were rather low $(<50 \%)$ with 1 wt $\%$ of both enzymes (entries 1 and 2 ). As such, the remaining tests were carried out with 5 wt \%.

In this case, CalB immo Plus showed a significantly higher activity, leading to $91 \%$ conversion (entry 4). The stirring speed was increased to check the mass transfer limitations, and it became clear that such limitations exist for both enzymes, given the acceleration of both reactions (entries 5 and 6) but 
Table 5. Enzymatic Transesterification of Fish Oil FAEEs with $\mathrm{HD}^{a}$

\begin{tabular}{cllcrrrr} 
& & & & \multicolumn{3}{c}{$\%$ conv } \\
\cline { 5 - 8 } entry & & enzyme (wt \%) & solvent & $\begin{array}{c}\text { stirring } \\
\text { (rpm.) }\end{array}$ & 1 h & $3 \mathrm{~h}$ & 6 h \\
1 & Novozym 435 (1) & no & 200 & 19 & 30 & 49 \\
2 & CalB immo Plus (1) & no & 200 & 9 & 24 & 44 \\
3 & Novozym 435 (5) & no & 200 & 31 & 46 & 74 \\
4 & CalB immo Plus (5) & no & 200 & 40 & 74 & 91 \\
5 & Novozym 435 (5) & no & 400 & 38 & 75 & 93 \\
6 & CalB immo Plus (5) & no & 400 & 72 & 90 & 96 \\
7 & Novozym 435 (5) & $t \mathrm{BuOH}$ & 200 & 62 & 86 & 95 \\
8 & CalB immo Plus (5) & $t \mathrm{BuOH}$ & 200 & 70 & 88 & 95
\end{tabular}

${ }^{a}$ Reaction conditions: 1.5 equiv, $\mathrm{HD}, 60^{\circ} \mathrm{C}$, and $10 \mathrm{mbar}$.

always with a clear advantage of CalB immo Plus. A similar effect was obtained when using tert-butanol as a solvent (entries 7 and 8) to increase the miscibility of the reagents. Under these conditions, both enzymes behave in a similar manner; therefore, the differences observed in the absence of a solvent may be because of the different hydrophilicity/ hydrophobicity of the support. Thus, the more hydrophobic support of CalB immo Plus (styrene-methacrylate) seems to be more suitable for a highly hydrophobic reaction medium, such as that of FAEEs and a large alcohol. The role of the hydrophobic character of the supported lipase on the transesterification activity has been noted by other authors. ${ }^{40}$ The addition of tert-butanol is likely to reduce the hydrophobic character of the mixture, thus meaning that the more hydrophilic support of Novozym 435 is then as efficient as the other one.

Both enzymes were recovered and reused in both types of conditions (higher stirring rate and addition of tert-butanol). The results are shown in Figure 5.
In all cases, both enzymes behave better than they did in the transesterification with $\mathrm{EH}$, thus indicating the effect of the alcohol $^{41}$ on the activity and the recoverability of the enzymes. At $400 \mathrm{rpm}$, recoveries of Novozym 435 (Figure 5A) were slightly better than those for the fresh enzyme, whereas with CalB immo Plus (Figure 5B), the behavior was the opposite, with slightly lower performance after reuse, but with a stable behavior. Stability improved yet further when $t \mathrm{BuOH}$ was added as a cosolvent (Figure 5C,D).

Transesterification Reactions with Isopropanol. As in the case of the base-catalyzed transesterifications, reactions were carried out at atmospheric pressure with a large excess (50 equiv) of isopropanol (Table 6). CalB immo Plus was slightly

Table 6. Enzymatic Transesterification of Fish Oil FAEEs with Isopropanol $(\mathrm{iPrOH})^{a}$

\begin{tabular}{cccccc} 
& & & \multicolumn{3}{c}{$\%$ conv } \\
\cline { 4 - 6 } entry & enzyme & stirring $(\mathrm{rpm})$ & $1 \mathrm{~h}$ & $6 \mathrm{~h}$ & $24 \mathrm{~h}$ \\
1 & Novozym 435 & 200 & 23 & 45 & 65 \\
2 & CalB immo Plus & 200 & 28 & 66 & 78 \\
3 & CalB immo Plus & 500 & 26 & 47 & 59
\end{tabular}

${ }^{a}$ Reaction conditions: 50 equiv, $i \mathrm{PrOH}, 5$ wt $\%$ enzyme, and $60{ }^{\circ} \mathrm{C}$.

more efficient than Novozym 435, giving $78 \%$ conversion after $24 \mathrm{~h}$. This result was not improved by distillation of the mixture of solvents and addition of new isopropanol, which seems to indicate a deactivation of the immobilized lipase, an effect described for small alcohols, such as methanol or ethanol, ${ }^{42}$ and which is still being studied. ${ }^{43}$ A higher stirring speed produced a decrease in the conversion, probably because of mechanical attrition of the immobilized enzyme. As such, the enzymatic approach is less efficient than the chemical one for transesterification with isopropanol.
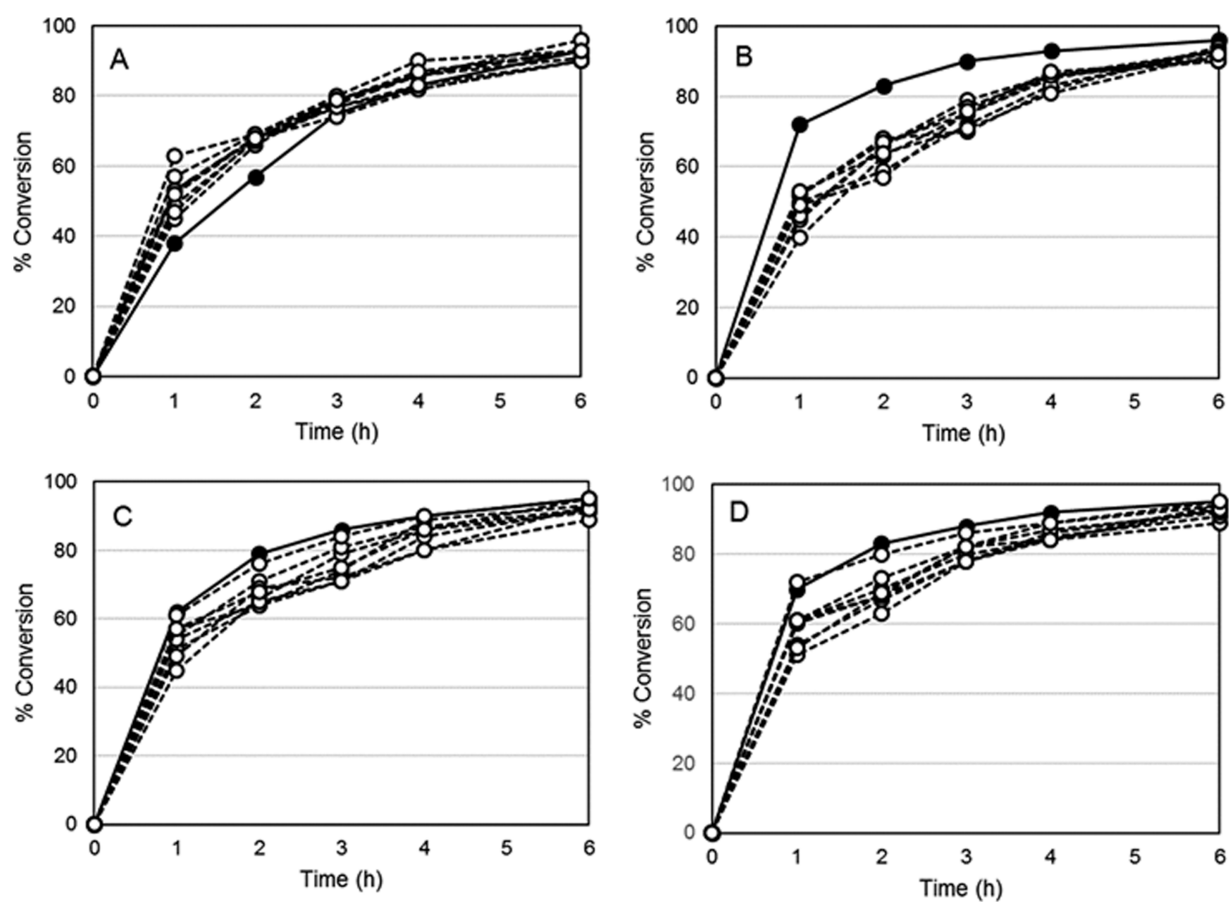

Figure 5. Transesterification of FAEEs with HD. First use (-) and eight successive reuses (O) of: (A) Novozym 435 at 400 rpm.; (B) CalB immo Plus at $400 \mathrm{rpm}$.; (C) Novozym 435 with $t \mathrm{BuOH}$; and (D) CalB immo Plus with $t \mathrm{BuOH}$. 
Economic Considerations. Apart from the chemical results, the choice of one or another synthetic method for production requires an economic estimation of the production costs that take into account the cost of reagents, catalysts, and cosolvents (if any) and energy costs. ${ }^{15}$ For this purpose, the cost of transforming $1000 \mathrm{~kg}$ of waste fish oil FAEEs was calculated by the management control department of Solutex, taking into account direct costs, including reagents and catalyst costs (considering the possibility of reuse in the case of immobilized lipases), energy costs (gas, electricity, vapor, and water) associated with the type of the reactor, heating temperature, vacuum pumps, and operating time and separation and analytical procedures and workforce. The results of this evaluation are gathered and shown in Table 7.

Table 7. Cost Evaluation for the Different

Transesterification Methods for Synthesizing Esters from Waste Fish Oil FAEEs (1000 kg Scale)

$\begin{array}{llcc}\text { alcohol } & \text { synthetic method } & \text { cosolvent } & \text { cost }(€ / \mathrm{kg}) \\ \mathrm{EH} & \text { chemical }(\mathrm{KOH}) & & 2.99 \\ & \text { chemical (EtONa) } & & 2.92 \\ & \text { enzymatic } & 3.40 \\ \mathrm{HD} & \text { chemical (KOH) } & & 4.32 \\ & \text { chemical (EtONa) } & & 4.06 \\ & \text { chemical (EtONa) } & \text { tert-Butanol } & 8.87 \\ & \text { enzymatic } & & 5.61 \\ & \text { enzymatic } & \text { tert-Butanol } & 7.74 \\ \text { isopropanol } & \text { chemical (EtONa) } & & 2.85 \\ & \text { enzymatic } & & 8.47\end{array}$

As can be seen, the costs for the synthesis of $\mathrm{EH}$ esters are very similar for all methods; therefore, the choice of which method to use is likely to be defined by other industrial variables based on the company's activities, such as use of the catalyst in other processes or safety considerations. In the case of HD esters, it is clear that the use of tert-butanol as a cosolvent is a key parameter that makes the procedure economically less attractive. Production using the enzymatic method is less cost-effective, despite the recoverability of the enzyme, although the impact of tert-butanol on the final cost is lower. Finally, the low yields obtained with isopropanol when using the enzymatic method make this system significantly more expensive than the chemical method using EtONa.

Properties of the Fatty Esters. One of the possible uses of these fatty esters is as lubricants. Thus, the physical properties of the mixtures, mainly viscosity and its change with temperature (viscosity index), together with others, such as pour point and flash point, ${ }^{44,45}$ were measured and compared with those for the starting mixture of ethyl esters $(\mathrm{Et})$. In the case of 2-hexyl-1-decyl esters, the mixture obtained was a solid at $40{ }^{\circ} \mathrm{C}$; hence, the properties were not determined. The results are collected and represented in Table 8 , together with their classification according to their kinematic viscosities (ISO-VG), which affects the possible applications.

As expected, the presence of branched alkyl groups from the alcohols used increases the kinematic viscosity values, especially in the case of 2-ethyl-1-hexyl, with values in the range of ISO-VG 10, whereas isopropyl reaches only ISO-VG5.

When compared with $\mathrm{EH}$ esters of plant origin, the kinematic viscosity of the esters from waste fish oil at $40{ }^{\circ} \mathrm{C}$ is significantly higher. In the case of vegetable oils, values range
Table 8. Properties of the Starting Ethyl Ester Mixture and the Different Esters

\begin{tabular}{lccc} 
& \multicolumn{3}{c}{ mixture of esters } \\
\cline { 2 - 4 } \multicolumn{1}{c}{ property } & Et & EH & iPr \\
density at $20{ }^{\circ} \mathrm{C}\left(\mathrm{g} / \mathrm{cm}^{3}\right)$ & 0.862 & 0.872 & 0.864 \\
kinematic viscosity at $40{ }^{\circ} \mathrm{C}(\mathrm{cSt})$ & 3.75 & 9.34 & 4.95 \\
viscosity ISO-VG & 3 & 10 & 5 \\
kinematic viscosity at $100{ }^{\circ} \mathrm{C}(\mathrm{cSt})$ & 1.60 & 2.74 & 1.88 \\
viscosity index & & 143 & 215 \\
flash point $\left({ }^{\circ} \mathrm{C}\right)$ & 176 & 207 & 176 \\
pour point $\left({ }^{\circ} \mathrm{C}\right)$ & -11 & -11 & -4 \\
\hline
\end{tabular}

from $7.8 \mathrm{cSt}$ for esters from rapeseed oil $^{17}$ up to $8.9 \mathrm{cSt}$ for esters from sal fat oil, ${ }^{46}$ with values close to $8 \mathrm{cSt}$ for esters from rubber seed oil $^{6}$ and palm oil ${ }^{8}$ also being reported. However, the kinematic viscosity at $100{ }^{\circ} \mathrm{C}$ is similar in all cases $(2.5-3 \mathrm{cSt})$.

In the case of isopropyl esters, the literature data are less complete and only a couple of kinematic viscosity values at 40 ${ }^{\circ} \mathrm{C}$, close to the value of $4.95 \mathrm{cSt}$ for waste fish oil esters, have been reported. ${ }^{3,47}$

The viscosity values of these esters appear to make them suitable for applications such as drilling fluids, spindle bearings, precision grinders, or low pressure hydraulic systems. However, further studies, including thermal and oxidation stability, would be required to assess their usability.

\section{CONCLUSIONS}

Two types of transesterification methods, namely, base catalysis and biocatalysis with immobilized lipases, have been optimized for the transformation of waste fish oil fatty esters with branched alcohols. The comparison of both methodologies shows that the most efficient method depends on the nature of the alcohol. The base-catalyzed transesterification is clearly more efficient in the case of isopropanol. On the contrary, the lipases are more efficient in the case of the larger $\mathrm{HD}$, given that they are easily recycled and reused without the loss of activity for at least eight runs. Both methods are efficient with $\mathrm{EH}$, but immobilized lipases progressively lose activity upon recycling and reuse. Additionally, the economic estimation of the processes indicates that the enzymatic transesterification is only competitive in the case of $\mathrm{EH}$, whereas the chemical transesterification is more favorable with the other two alcohols. Overall, this comparison shows the possibility to choose a chemical or an enzymatic pathway depending on the alcohol needed to carry out the transesterification, focusing on the possible applicability of the products. Regarding the possible applications, isopropyl and 2ethyl-1-hexyl esters show interesting properties as potential biolubricants, whereas 2-hexyl-1-decyl esters are solid at room temperature and therefore other applications working at higher temperatures could be more suitable.

\section{EXPERIMENTAL SECTION}

Base-Catalyzed Transesterification Reactions. All the reactions were carried out in two-neck round-bottom flasks equipped with a septum in the side neck and a reflux condenser connected to a cooling circuit $\left(15{ }^{\circ} \mathrm{C}\right)$. The reactants were heated with silicone oil baths at the reported temperature. In the case of reactions at low pressure, the upper side of the reflux condenser was connected to a vacuum pump 
and a manometer, with a liquid $\mathrm{N}_{2}$ trap to condense the vapor before the pump.

Reaction with EH. The reaction was carried out with a 150:100:1 alcohol/FAEE/base molar ratio. A mixture of 0.1 mmol base (KOH, EtONa, or TBD), $1.98 \mathrm{~g}$ of $\mathrm{EH}$ (15.18 $\mathrm{mmol})$, and $3 \mathrm{~g}$ of fish oil FAEEs $(10.12 \mathrm{mmol})$ was stirred at $1500 \mathrm{rpm}$ and $90{ }^{\circ} \mathrm{C}$ under vacuum (10 mbar). Aliquot samples were taken at different reaction times and they were analyzed by gas chromatography until total conversion was reached. The crude was diluted with water $(10 \mathrm{~mL})$, and $\mathrm{HCl}$ (35 wt \%) was added drop wise until neutral $\mathrm{pH}$. The aqueous phase was extracted with $\mathrm{CH}_{2} \mathrm{Cl}_{2}(4 \times 10 \mathrm{~mL})$, the combined organic phases were dried with anhydrous $\mathrm{MgSO}_{4}$ and then filtered, and the solvent and the excess of alcohol were eliminated under reduced pressure. The yield was $84( \pm 2) \%$ in all the cases, irrespective of the base used. The same result was obtained after scaling-up this method to $100 \mathrm{~g}$ of FAEEs.

Reaction with HD. The procedure was the same as described above, using $0.1 \mathrm{mmol} \mathrm{KOH}$ or $0.5 \mathrm{mmol}$ EtONa as a base. Additionally, the reaction temperature had to be increased to $120^{\circ} \mathrm{C}$ or tert-butanol $(5 \mathrm{~mL})$ was added in the reaction at $90{ }^{\circ} \mathrm{C}$. The excess of alcohol was eliminated by filtration through a silica pad and washing with hexanes. The yield was $73( \pm 2) \%$ in all the cases, irrespective of the base used.

Reaction with Isopropanol. As vacuum cannot be used, the experimental procedure was different from the procedure described above. The isopropanol/FAEE/EtONa molar ratio was 5000:100:10. A solution of $68.8 \mathrm{mg}$ of EtONa $(1 \mathrm{mmol})$ and $3 \mathrm{~g}$ of fish oil FAEEs $(10.12 \mathrm{mmol})$ in $38.5 \mathrm{~mL}$ of isopropanol $(500 \mathrm{mmol})$ was stirred at $1500 \mathrm{rpm}$ under reflux for $1 \mathrm{~h}$. After evaporation of the solvents, the crude was neutralized and extracted as indicated above. The yield was $88 \%$.

The same procedure was followed for the scaled-up reaction with $100 \mathrm{~g}$ of fish oil FAEEs, using $2.32 \mathrm{~g}$ of EtONa and 478 $\mathrm{mL}$ of isopropanol (molar ratio 3000:100:10). To get full conversion of FAEEs, the reaction was started with an isopropanol/FAEE/EtONa molar ratio of only 1000:100:5 (160 mL of isopropanol and $1.16 \mathrm{~g}$ of EtONa). After $1 \mathrm{~h}$ under reflux, the mixture of solvents was evaporated under vacuum and a solution of $1.16 \mathrm{~g}$ of EtONa in $160 \mathrm{~mL}$ of isopropanol was added. After 1 additional hour under reflux, the solvents were again evaporated and another solution of EtONa in isopropanol was added. The final FAEE/EtONa molar ratio was then 100:15. After $1 \mathrm{~h}$ under reflux, the solvents were evaporated under vacuum and the reaction mixture was neutralized as described above. The yield under those conditions was $89( \pm 1) \%$ (average of three reactions).

Enzymatic Transesterification Reactions. Reaction with $\mathrm{EH}$. A mixture of $150 \mathrm{mg}$ of the immobilized enzyme, $1.98 \mathrm{~g}$ of $\mathrm{EH}(15.18 \mathrm{mmol})$, and $3 \mathrm{~g}$ of fish oil FAEEs $(10.12$ mmol) was stirred at $200 \mathrm{rpm}$ and $60{ }^{\circ} \mathrm{C}$ under vacuum (10 mbar). Aliquot samples were taken at different reaction times and they were analyzed by gas chromatography until total conversion was reached. The enzyme was filtered off and washed with acetone $(15 \mathrm{~mL})$. The acetone and the excess of alcohol were eliminated under reduced pressure. The yield was $89( \pm 2) \%$ (average of three reactions with each enzyme). The enzyme was dried and reused under the same conditions.

Reaction with $H D$. The procedure was the same as described above, but the stirring rate was increased to 400 $\mathrm{rpm}$, or tert-butanol $(5 \mathrm{~mL})$ was added when stirring was kept at $200 \mathrm{rpm}$. After filtering and washing of the enzyme, the crude was filtered through a silica pad and washed with hexanes to eliminate the excess of alcohol. The yield was $76( \pm 2) \%$ in all the cases.

Reaction with Isopropanol. A mixture of $150 \mathrm{mg}$ of the immobilized enzyme, $3 \mathrm{~g}$ of fish oil FAEEs $(10.12 \mathrm{mmol})$, and $38.5 \mathrm{~mL}$ of isopropanol was stirred at $200 \mathrm{rpm}$ and $60^{\circ} \mathrm{C}$ for 6 h. After that time, the isopropanol/ethanol mixture was distilled, $38.5 \mathrm{~mL}$ of isopropanol was added, and the reaction was stirred under the same conditions for $18 \mathrm{~h}$. The reaction mixture was treated as described above to obtain $80 \%$ conversion of the FAEEs (single reaction).

Chromatographic Methods. The chromatographic analysis of the reactions was carried out using Agilent 7890A and 6890 chromatographs with flame ionization detectors and ZB5HT Inferno $(30 \mathrm{~m} \times 0.25 \mathrm{~mm} \times 0.25 \mu \mathrm{m})$ columns. The diluted (dichloromethane) samples were injected at $250{ }^{\circ} \mathrm{C}$ with a split ratio of $30: 1$ and a column head pressure of 24.7 psi (carrier $\mathrm{He}$ ). The detector temperature was $280{ }^{\circ} \mathrm{C}$. As the conversion was similar for all the FAs, the results were taken from the areas of the palmitates. The full chromatograms are collected and are shown in the Supporting Information.

Transesterification with $E H$. Oven temperature program: $180{ }^{\circ} \mathrm{C}(5 \mathrm{~min})-2{ }^{\circ} \mathrm{C} / \mathrm{min}-250{ }^{\circ} \mathrm{C}(20 \mathrm{~min})$. Retention times: EH $2.3 \mathrm{~min}$, ethyl palmitate $15.2 \mathrm{~min}$, and 2-ethyl-1hexyl palmitate $34.1 \mathrm{~min}$.

Transesterification with $H D$. Oven temperature program: $180{ }^{\circ} \mathrm{C}(5 \mathrm{~min})-2{ }^{\circ} \mathrm{C} / \mathrm{min}-200{ }^{\circ} \mathrm{C}(0 \mathrm{~min})-5{ }^{\circ} \mathrm{C} / \mathrm{min}-$ $300{ }^{\circ} \mathrm{C}(20 \mathrm{~min})$. Retention times: HD $8.9 \mathrm{~min}$, ethyl palmitate $13.4 \mathrm{~min}$, and 2-hexyl-1-decyl palmitate $34.2 \mathrm{~min}$.

Transesterification with Isopropanol. Oven temperature program: $180{ }^{\circ} \mathrm{C}(5 \mathrm{~min})-2{ }^{\circ} \mathrm{C} / \mathrm{min}-250{ }^{\circ} \mathrm{C}(20 \mathrm{~min})$. Retention times: isopropanol $1.5 \mathrm{~min}$ (overlapped with dilution solvent), ethyl palmitate $13.4 \mathrm{~min}$, and isopropyl palmitate $16.1 \mathrm{~min}$.

Characterization of the Properties of the Fatty Esters. The density at $20{ }^{\circ} \mathrm{C}$ was determined according to the UNE 84156:2000 method. The kinematic viscosities were determined at 40 and $100{ }^{\circ} \mathrm{C}$ based on the American Society for Testing and Materials (ASTM) D445 method. The viscosity index was calculated from kinematic viscosities according to the ASTM D-2270-10 method. The pour point was determined according to the ASTM D5950-14. The flash point was determined according to the ASTM D92-16b.

\section{ASSOCIATED CONTENT}

\section{Supporting Information}

The Supporting Information is available free of charge at https://pubs.acs.org/doi/10.1021/acsomega.9b03147.

Gas chromatographs of the starting mixture of waste fish oil FAEEs and the reaction mixtures with the three alcohols (PDF)

\section{AUTHOR INFORMATION}

\section{Corresponding Authors}

*E-mail: jmfraile@unizar.es (J.M.F.).

*E-mail: clarah@unizar.es (C.I.H.).

ORCID

José M. Fraile: 0000-0002-0136-5138

Clara I. Herrerías: 0000-0002-7272-8506

Notes

The authors declare no competing financial interest. 


\section{ACKNOWLEDGMENTS}

This work was financed by the Spanish Ministerio de Ciencia, Innovación y Universidades [project number RTI2018093431-B-I00], and the Gobierno de Aragón [E37 17R group]. B.A. acknowledges Solutex GC S.L. together with the University of Zaragoza [project OTRI 2015/0231, program of industrial doctorates] for the financial support of her $\mathrm{PhD}$.

\section{ABBREVIATIONS}

ASTM, American Society for Testing and Materials; EH, 2ethyl-1-hexanol; FAs, fatty acids; FAEEs, fatty acid ethyl esters; FAMEs, fatty acid methyl esters; HD, 2-hexyl-1-decanol; ${ }^{i} \mathrm{PrOH}$, isopropanol; ISO, International Standards Organization; ISO-VG, International Standards Organization Viscosity Grade; MUFAs, monounsaturated fatty acids; PUFAs, polyunsaturated fatty acids; SFAs, saturated fatty acids; TBD, 1,5,7-triazabicyclo[4.4.0] dec-5-ene; UNE, Una Norma Española (a Spanish standard)

\section{ADDITIONAL NOTES}

${ }^{a}$ https://www.novozymes.com/-/media/Project/Novozymes/ Website/website/document-library/Advance-your-business/ Pharma/Biocatalysis brochure Immobilised Lipases.pdf.

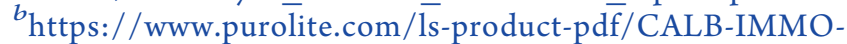
PLUS.pdf.

\section{REFERENCES}

(1) Fukuda, H.; Kondo, A.; Noda, H. Biodiesel fuel production by transesterification of oils. J. Biosci. Bioeng. 2001, 92, 405-416.

(2) Wang, P. S.; Tat, M. E.; Van Gerpen, J. The production of fatty acid isopropyl esters and their use as a diesel engine fuel. J. Am. Oil Chem. Soc. 2005, 82, 845-849.

(3) Silva, L. N.; Cardoso, C. C.; Pasa, V. M. D. Synthesis and characterization of esters from different alcohols using Macauba almond oil to substitute diesel oil and jet fuel. Fuel 2016, 166, 453460.

(4) Aarthy, M.; Saravanan, P.; Gowthaman, M. K.; Rose, C.; Kamini, N. R. Enzymatic transesterification for production of biodiesel using yeast lipases: An overview. Chem. Eng. Res. Des. 2014, 92, 1591-1601.

(5) Hama, S.; Noda, H.; Kondo, A. How lipase technology contributes to evolution of biodiesel production using multiple feedstocks. Curr. Opin. Biotechnol. 2018, 50, 57-64.

(6) Kamalakar, K.; Rajak, A. K.; Prasad, R. B. N.; Karuna, M. S. L. Rubber seed oil-based biolubricant base stocks: A potential source for hydraulic oils. Ind. Crops Prod. 2013, 51, 249-257.

(7) Herrmann, C.; Hesselbach, J.; Bock, R.; Zein, A.; Öhlschläger, G.; Dettmer, T. Ecologically benign lubricants - Evaluation from a life cycle perspective. Clean: Soil, Air, Water 2007, 35, 427-432.

(8) Habib, N. S. H. A.; Yunus, R.; Rashid, U.; Taufiq-yap, Y. H.; Abidin, Z. Z.; Syam, A. M.; Irawan, S. Transesterification Reaction for Synthesis of Palm- based Ethylhexyl Ester and Formulation as Base Oil for Synthetic Drilling Fluid. J. Oleo Sci. 2014, 63, 497-506.

(9) Park, J. M.; Kim, Y. H.; Kim, S. B. Development of Solvent-Free Offset Ink Using Vegetable Oil Esters and High Molecular-Weight Resin. J. Oleo Sci. 2013, 62, 345-352.

(10) Aydemir, C.; Yenidoğan, S.; Karademir, A.; Arman Kandirmaz, E. The examination of vegetable- and mineral oil-based inks' effects on print quality Green printing effects with different oils. J. Appl. Biomater. Funct. Mater. 2018, 16, 137-143.

(11) Lee, I.; Johnson, L. A.; Hammond, E. G. Use of branched-chain esters to reduce the crystallization temperature of biodiesel. J. Am. Oil Chem. Soc. 1995, 72, 1155-1160.

(12) De Torres, M.; Jiménez-Osés, G.; Mayoral, J. A.; Pires, E. Fatty acid derivatives and their use as CFPP additives in biodiesel. Bioresour. Technol. 2011, 102, 2590-2594.
(13) Biermann, U.; Butte, W.; Holtgrefe, R.; Feder, W.; Metzger, J. $\mathrm{O}$. Esters of calendula oil and tung oil as reactive diluents for alkyd resins. Eur. J. Lipid Sci. Technol. 2010, 112, 103-109.

(14) Waskitoaji, W.; Triwulandari, E.; Haryono, A. Synthesis of Plasticizers Derived from Palm Oil and Their Application in Polyvinyl Chloride. Procedia Chem. 2012, 4, 313-321.

(15) Murcia, M. D.; Serrano-Arnaldos, M.; Ortega-Requena, S.; Máximo, F.; Bastida, J.; Montiel, M. C. Optimization of a sustainable biocatalytic process for the synthesis of ethylhexyl fatty acids esters. Catal. Today 2019, DOI: 10.1016/j.cattod.2019.03.055, , in press.

(16) Kleinaite, E.; Jaška, V.; Tvaska, B.; Matijošyte, I. A cleaner approach for biolubricant production using biodiesel as a starting material. J. Cleaner Prod. 2014, 75, 40-44.

(17) Gryglewicz, S.; Muszyński, M.; Nowicki, J. Enzymatic synthesis of rapeseed oil-based lubricants. Ind. Crops Prod. 2013, 45, 25-29.

(18) Linko, Y.-Y.; Lämsä, M.; Huhtala, A.; Linko, P. Lipase-catalyzed transesterification of rapeseed oil and 2-ethyl-1-hexanol. J. Am. Oil Chem. Soc. 1994, 71, 1411-1414.

(19) Wu, X. Y.; Jäskeläinen, S.; Linko, Y.-Y. An investigation of crude lipases for hydrolysis, esterification, and transesterification. Enzyme Microb. Technol. 1996, 19, 226-231.

(20) Baldo, F.; Guiramand, C. Composition containing at least one bicyclic aromatic compound and at least one lipophilic sunscreen, and uses thereof. U.S. Patent 6,391,287B1, 2002.

(21) Ansmann, A.; Dierker, M. Esters of hexyldecanol having shortchained fatty acids. U.S. Patent 8,158,680B2, 2012.

(22) Likozar, B.; Levec, J. Transesterification of canola, palm, peanut, soybean and sunflower oil with methanol, ethanol, isopropanol, butanol and tert-butanol to biodiesel: Modelling of chemical equilibrium, reaction kinetics and mass transfer based on fatty acid composition. Appl. Energy 2014, 123, 108-120.

(23) Naranjo, J. C.; Córdoba, A.; Giraldo, L.; García, V. S.; MorenoPiraján, J. C. Lipase supported on granular activated carbon and activated carbon cloth as a catalyst in the synthesis of biodiesel fuel. $J$. Mol. Catal. B: Enzym. 2010, 66, 166-171.

(24) Tokuyama, S.; Nakamoto, K. Pain as modified by polyunsaturated fatty acids. In Omega-3 Fatty Acids in Brain and Neurological Health; Watson, R. R., De Meester, F., Eds.; Academic Press: London, 2014; pp 131-146.

(25) Ruxton, C. H. S.; Calder, P. C.; Reed, S. C.; Simpson, M. J. A. The impact of long-chain $\mathrm{n}-3$ polyunsaturated fatty acids on human health. Nutr. Res. Rev. 2005, 18, 113.

(26) Rubio-Rodríguez, N.; Beltrán, S.; Jaime, I.; de Diego, S. M.; Sanz, M. T.; Carballido, J. R. Production of omega-3 polyunsaturated fatty acid concentrates: A review. Innovative Food Sci. Emerging Technol. 2010, 11, 1-12.

(27) Korhonen, J.; Nuur, C.; Feldmann, A.; Birkie, S. E. Circular economy as an essentially contested concept. J. Cleaner Prod. 2018, $175,544-552$.

(28) Yuvaraj, D.; Bharathiraja, B.; Rithika, J.; Dhanasree, S.; Ezhilarasi, V.; Lavanya, A.; Praveenkumar, R. Production of biofuels from fish wastes: an overview. Biofuels 2016, 10, 301-307.

(29) Dave, D.; Ramakrishnan, V. V.; Trenholm, S.; Manuel, H.; Pohling, J.; Murphy, W. Marine Oils as Potential Feedstock for Biodiesel Production: Physicochemical Characterization. J. Bioprocess. Biotech. 2014, 04. DOI: DOI: 10.4172/2155-9821.1000168.

(30) Costa, J. F.; Almeida, M. F.; Alvim-Ferraz, M. C. M.; Dias, J. M. Biodiesel production using oil from fish canning industry wastes. Energy Convers. Manage. 2013, 74, 17-23.

(31) Arumugam, A.; Ponnusami, V. Production of biodiesel by enzymatic transesterification of waste sardine oil and evaluation of its engine performance. Heliyon 2017, 3, No. e00486.

(32) do Valle, C. P.; Rodrigues, J. S.; Fechine, L. M. U. D.; Cunha, A. P.; Queiroz Malveira, J.; Luna, F. M. T.; Ricardo, N. M. P. S. Chemical modification of Tilapia oil for biolubricant applications. J. Cleaner Prod. 2018, 191, 158-166.

(33) Galli, F.; Nucci, S.; Pirola, C.; Bianchi, C. L. Epoxy methyl soyate as bio-plasticizer: Two different preparation strategies. Chem. Eng. Trans. 2014, 37, 601-606. 
(34) Angulo, B.; Fraile, J. M.; Gil, L.; Herrerías, C. I. Bio-lubricants production from fish oil residue by transesterification with trimethylolpropane. J. Cleaner Prod. 2018, 202, 81.

(35) Tacias-Pascacio, V. G.; Torrestiana-Sánchez, B.; Dal Magro, L.; Virgen-Ortíz, J. J.; Suárez-Ruíz, F. J.; Rodrigues, R. C.; FernandezLafuente, R. Comparison of acid, basic and enzymatic catalysis on the production of biodiesel after RSM optimization. Renewable Energy 2019, 135, 1-9.

(36) Pirola, C.; Galli, F.; Bianchi, C. L.; Boffito, D. C.; Comazzi, A.; Manenti, F. Vegetable oil deacidification by methanol heterogeneously catalyzed esterification in (monophasic liquid)/solid batch and continuous reactors. Energy Fuels 2014, 28, 5236-5240.

(37) Boffito, D. C.; Galli, F.; Martinez, P. R.; Pirola, C.; Bianchi, C. L.; Patience, G. S. Transesterification of Triglycerides in a New Ultrasonic-Assisted Mixing Device. Chem. Eng. Trans. 2015, 43, 427432.

(38) Boffito, D. C.; Galli, F.; Pirola, C.; Patience, G. S. CaO and isopropanol transesterify and crack triglycerides to isopropyl esters and green diesel. Energy Convers. Manage. 2017, 139, 71-78.

(39) Li, L.; Du, W.; Liu, D.; Wang, L.; Li, Z. Lipase-catalyzed transesterification of rapeseed oils for biodiesel production with a novel organic solvent as the reaction medium. J. Mol. Catal. B: Enzym. 2006, 43, 58-62.

(40) Villalba, M.; Verdasco-Martín, C. M.; dos Santos, J. C. S.; Fernandez-Lafuente, R.; Otero, C. Operational stabilities of different chemical derivatives of Novozym 435 in an alcoholysis reaction. Enzyme Microb. Technol. 2016, 90, 35-44.

(41) Kouteu, P. A. N.; Blin, J.; Baréa, B.; Barouh, N.; Villeneuve, P. Solvent-free biodiesel production catalyzed by crude lipase powder from seeds: Effects of alcohol polarity, glycerol, and thermodynamic water activity. J. Agric. Food Chem. 2017, 65, 8683-8690.

(42) Watanabe, Y.; Shimada, Y.; Sugihara, A.; Tominaga, Y. Stepwise ethanolysis of tuna oil using immobilized Candida antarctica lipase. J. Biosci. Bioeng. 1999, 88, 622-626.

(43) José, C.; Bonetto, R. D.; Gambaro, L. A.; Torres, M. d. P. G.; Foresti, M. L.; Ferreira, M. L.; Briand, L. E. Investigation of the causes of deactivation-degradation of the commercial biocatalyst Novozym ${ }^{\circledR}$ 435 in ethanol and ethanol-aqueous media. J. Mol. Catal. B: Enzym. 2011, 71, 95-107.

(44) Mobarak, H. M.; Niza Mohamad, E.; Masjuki, H. H.; Kalam, M. A.; Al Mahmud, K. A. H.; Habibullah, M.; Ashraful, A. M. The prospects of biolubricants as alternatives in automotive applications. Renewable Sustainable Energy Rev. 2014, 33, 34-43.

(45) Zainal, N. A.; Zulkifli, N. W. M.; Gulzar, M.; Masjuki, H. H. A review on the chemistry, production, and technological potential of bio-based lubricants. Renewable Sustainable Energy Rev. 2018, 82, 80102.

(46) Kamalakar, K.; Manoj, G. N. V. T. S.; Prasad, R. B. N.; Karuna, M. S. L. Influence of structural modification on lubricant properties of sal fat-based lubricant base stocks. Ind. Crops Prod. 2015, 76, 456466.

(47) May, C.; Liang, Y.; Foon, C.; Ngan, M.; Chenghook, C.; Basiron, Y. Key fuel properties of palm oil alkyl esters. Fuel 2005, 84, $1717-1720$. 